\title{
The role of arbuscular mycorrhizae in primary succession: differences and similarities across habitats
}

\author{
Z. Kikvidze, C. Armas, K. Fukuda, L. B. Martínez-García, M. Miyata, A. Oda-Tanaka, F. I. Pugnaire and \\ B. Wu
}

Kikvidze, Z., Armas, C., Fukuda, K., Martínez-García, L. B., Miyata, M., Oda-Tanaka, A., Pugnaire, F. I. and Wu, B. 2010. The role of arbuscular mycorrhizae in primary succession: differences and similarities across habitats. - Web Ecol. 10: 50-57.

\begin{abstract}
Primary succession is an ecological process of fundamental importance referring to the development of vegetation on areas not previously occupied by a plant community. The bulk of knowledge on primary succession comes from areas affected by relatively recent volcanic eruptions, and highlights the importance of symbiosis between host plants and fungi for the initial stages of succession. Arbuscular mycorrhizas (AM) are of particular interest as they are often present from the very beginning of primary succession and because they show different relationships with pioneer and late-successional species, which suggests they may be involved in important, yet unknown, ecological mechanisms of succession. We review existing knowledge based on case studies from the volcanic desert of Mount Fuji, Japan, where primary succession was examined intensively and which represents one of the best-known cases on the role of AM in primary succession. We also assess the potential of sand dunes and semi-arid, erosion-prone systems for addressing the role of mycorrhizas in primary succession. Analyzing primary succession under different ecological systems is critical to understand the role of AM in this basic process. While volcanoes and glaciers are restricted to particular mountainous areas, naturally eroded areas and sand dunes are more common and easily accessible, making them attractive models to study primary succession.
\end{abstract}

\begin{abstract}
Z. Kikvidze (zaal@k.u-tokyo.ac.jp), K. Fukuda, M. Miyata and A. Oda-Tanaka, Dept of Natural Environment, Univ. of Tokyo, 5-1-5 Kashiwanoha, Kashiwa, JP-277-8563 Chiba, Japan. - C. Armas, L. B. Martínez-Garcia and F. I. Pugnaire, Estación Experimental de Zonas Áridas, CSIC, Almeria, Spain. - B. Wu, Dept of Forest Ecology, Univ. of Tokyo, Yayoi 1-1-1 Bunkyo-ku, JP-113-8657 Tokyo, Japan.
\end{abstract}

Primary succession is an ecological process of fundamental importance and refers to the settlement and development of vegetation on an area that has not previously been occupied by a plant community, such as a newly exposed rock, sand surface, lava flows, or glacial tills. Because such strong geomorphologic and topographic changes affect a relatively minor part of the Earth's surface, there are not many opportunities to study naturally ongoing primary succession. The bulk of knowledge on primary succession comes from areas affected by relatively recent volcanic eruptions (ca 500-300 years ago to present), hence from regions of main volcanic activity such as Japan (Titus and Tsuyuzaki 2003, Tsuyuzaki and Hase 2005), the Aleutian islands (del Moral 2010), the Santorini archipelago in the Aegean sea (Dimipoulos et al. 2010), the South American Páramo (Sklenár et al. 2010), Hawaii (Aplet et al. 1998), or New Zealand (Walker et al. 2003). One particularly well-known case is Mount St Helens, Washington, USA 
(del Moral and Wood 1993) which is often used as reference (del Moral 2010). Receding glaciers provide another case of primary succession, although these are climatically biased because they are restricted to alpine-arctic regions (Garbarino et al. 2010, Marteinsdóttir et al. 2010, Robbins and Matthews 2010). Areas with intensive erosion and landslides (Walker et al. 2009) including arid ecosystems (Pezzani et al. 2006), as well as sand dunes (Gormally and Donovan 2010) can also provide chronosequences of land exposed to succession, although there is not much data on primary successions in these systems.

Certain generalizations can already be inferred from the studies conducted on primary succession. First, it is a rather slow process (del Moral and Jones 2002, Tsuyazaki and Hase 2005, Sklenár et al. 2010) limited by seed dispersal, essentially a random process which adds considerably stochastic character to early stages of primary succession (del Moral et al. 1995, Marteinsdóttir et al. 2010). However, deterministic processes are also present in early stages as a consequence of the effects of micro-topography or physical and chemical substrate properties (del Moral and Wood 1993, Aplet et al. 1998, Tu et al. 1998, Titus and Tsuyuzaki 2003, Tsuyuzaki and Hase 2005, Tsuyuzaki et al. 2005, Robbins and Matthews 2010). The importance of such environmental filters increases with time (Dimopoulos et al. 2010, Garbarino et al. 2010) and, as a result, there is poor correlation between the seed bank and standing vegetation (Tu et al. 1998). There is also an evident trade-off between dispersal and plant colonizing abilities that makes primary succession particularly slow; easily-dispersed species with light, small seeds lack the ability to establish until soils are developed, whilst species with large and heavy seeds are capable of establishment on bare ground but disperse poorly (del Moral and Wood 1993). Second, re-colonization from surviving vegetation patches is not an important process (Wood and del Moral 1987, del Moral and Eckert 2005) although such patches may still play a role as stepping stones to facilitate colonization by pioneer species (Fuller and del Moral 2003). The third and outstanding generalization is that belowground symbiotic organisms may play a critical role in primary succession. For example, nitrogen-fixing bacteria help their host plants to colonize barren soil-less areas (del Moral and Wood 1993, Walker et al. 2003), and such plants can be key elements of succession by accelerating soil formation (del Moral and Rozzell 2005). Although there are data on fungal symbiotic associations, mechanisms of plant-fungus interactions in primary succession are poorly known and make understanding of primary succession especially challenging (Trowbridge and Jumpponen 2004).

\section{The importance of mycorrhiza}

Mycorrhizas play a vital role for many plant species, helping them to take up water, phosphorus and other nutrients.
The development of mycorrhizal symbiosis, particularly of arbuscular mycorrhiza (AM) most likely played a critical role in the initial colonization of land by plants and in the evolution of vascular species (Brundrett 2002). Mycorrhizal symbiosis enable plants to extract nutrients even from solid inorganic particles in very poor soils, and are important for sustaining plant growth in harsh environments like alpine tundra and alpine deserts (Cripps and Eddington 2005). Increased absorbing surface via fungi mycelia improves water relations of plants also in dry conditions (Morte et al. 2000, Allen et al 2003, Tian et al. 2006, Allen 2007). Pioneer species that start primary succession face especially harsh environments, and mycorrhizal symbiosis may mean a vital help. The importance of mycorrhiza in primary succession has been assessed mainly in volcanic deserts and glacier forefronts. Although there are clear patterns inferred from such studies, there are also important contradictions. The first idea is that different types of mycorrhiza may take part in primary succession depending on pioneer plant taxa. There are AM, ectomycorrhiza (EM), arbutoid, ericoid and orchid mycorrhiza on volcanic deserts of Japan (Tsuyuzaki et al. 2005, Obase et al. 2007, 2008), in glacier forefronts (Helm et al. 1996, Cázares et al. 2005), and alpine tundra (e.g. Beartooth Mountains; Cripps and Eddington 2005) playing overall an important role (Trowbridge and Jumpponen 2004). Second, EM and AM are strongly associated with pioneer woody species (Wu et al. 2001, Tsuyuzaki et al. 2005, Nara 2006, Obase et al. 2007) and some degree of host-specificity at the family level can be observed (Cázares et al. 2005, Cripps and Eddington 2005, Tsuyuzaki et al. 2005). Studies on AM, however, produced contradictory results. One controversial point concerns whether AM are important at the very early stages of succession (they are the dominant type of mycorrhiza in volcanic deserts such as Mount Fuji, Japan: Fujiyoshi et al. 2005, and in glacier forefronts: Cázares et al. 2005), or not (Obase et al. 2007, 2008). On Mount St Helens, Titus and del Moral (1998a) found that AM were not important for growth of facultative mycorrhizal plants, however in a greenhouse experiment these authors found that symbiosis with AM improved the competitive ability of these plants versus non-mycorrhized ones (Titus and del Moral 1998b). In the Chihuahuan desert, Pezzani et al. (2006) found that species entering the cyclical succession at late stages benefited more strongly from the symbiosis with AM, whilst species that colonized barren soils showed rather complex responses, being less or more receptive to mycorrhiza. Another unclear point concerns whether pioneer non-woody species are mycorrhizal; for example, Polygonum cuspidatum and $P$. weyrichii are two prominent pioneer species in volcanic deserts of Japan reported as mycorrhizal (although with low frequency, Fujiyoshi et al. 2005, Tsuyuzaki et al. 2005). Other studies, however, found mycorrhiza in $P$. cuspidatum but not in $P$. weyrichii (Wu et al. 2004, 2007) pointing to an influence of environmental conditions on the mycorrhization of 
these species (Fujiyoshi et al. 2005, Tsuyuzaki et al. 2005) and questioning whether pioneer species are mycorrhizadependent or not.

Nevertheless, AM are particularly interesting because they are often present from the very beginning of primary succession. At the same time, pioneer herbaceous species have zero to low rates of mycorrhizal infection, or have no or little benefit from AM symbiosis, whilst late-successional species clearly benefit from the symbiosis with AM. These different relationships of AM with pioneer and latesuccessional species suggest that AM may be involved in important and intricate, yet unknown, ecological mechanisms of primary succession. We present in the next section a case study focusing on the volcanic desert of Mount Fuji, Japan, where primary succession was examined intensively and which represents one of the best-known cases on the role of AM in primary succession. Afterwards, we assess the potential of sand dunes and semi-arid, erosion-prone systems for addressing the role of mycorrhizas in primary succession, where locally large-scale erosion events can expose virgin land to plant colonization, and thus, can serve as models for studying primary succession.

\section{AM in primary succession of vegetation: a case study on volcanic desert of Mount Fuji}

The last eruption of Mount Fuji in 1707 deposited a large amount of volcanic ash and scoria which destroyed all vegetation on the southeast slope of the volcano. Thus, current vegetation here is the result of some 300 years of primary succession (Fig. 1). Climatically this area should be a broadleaved deciduous forest (most probably dominated by beech Fagus crenata); indeed, the timberline reaches an elevation of ca $2500 \mathrm{~m}$ on undisturbed sides of the mountain whilst on the southeast slope forests remain only below $1300 \mathrm{~m}$ elevation. Patterns and some mechanisms of the succession going on in this slope have been long addressed (Maruta 1976, Hirose and Tateno 1984, Masuzawa and Suzuki 1991, Masuzawa 1995, 1997, Adachi et al. 1996, Nishitani and Masuzawa 1996, Zhou et al. 2003). Among the few pioneer species colonizing the barren scoria substrate, Polygomum cuspidatum stands out due to its ability to create vegetation patches where other species can establish. Plants in patches spread outwards so that shoot density decreases in the centre of the patch causing the central dieback phenomenon (Masuzawa 1995, Adachi et al. 1996). Nutrients accumulate at the centre and help colonization by other species. However, it is possible to see a different pattern of succession facilitated by $P$. cuspidatum in which protection from the impacts of moving, loose scoria is evident (Kikvidze et al. unpubl.). Patches are elongated along the slope. The upper part of such patches consists almost exclusively of $P$. cuspidatum, which probably receives and buffers the impact of scoria moving downwards. The middle and especially the lower parts of the patch, however, seem less disturbed and host late-successional species. Other pioneer species that can establish on barren scoria, such as the congeneric $P$. weyrichii, Arabis serrata or Miscanthus oligostachyus remain solitary on the volcanic ash and, in contrast to P. cuspidatum, do not take further part in succession. An exception is Cirsium purpuratum, which can establish and grow both in solitude or in P. cuspidatum patches. Cirsium purpuratum can grow even in the outer, most disturbed parts of vegetation patches. Overall, up to 30 species can be found at the lower part of this volcanic slope (Table 1), most of them spatially associated with $P$. cuspidatum.

Time is an inherent dimension of succession. However, the spatial dimension also becomes important on the slope of a mountain. In particular, the pace of succession seems to slow down considerably with increasing elevation on the southeast slope of Mount Fuji (Wu et al. 2007). First, species richness declines dramatically from ca 30 species at $1500 \mathrm{~m}$ to as few as four species at $1930 \mathrm{~m}$ a.s.l. Remarkably, plants at high elevation are exclusively early pioneer species able to colonize barren scoria $(A$. serrata, $C$. purpuratum, P. cuspidatum and P. weyrichii). Vegetation cover also declines from $15 \%$ at $1500 \mathrm{~m}$ to less than $5 \%$ at 1930 $\mathrm{m}$ a.s.l. In parallel, abundance of AM spores drops from 2.5 to $0.2 \mathrm{~g}^{-1}$ of dry soil, and the number of spore morphotypes (a surrogate for taxonomic richness) also declines

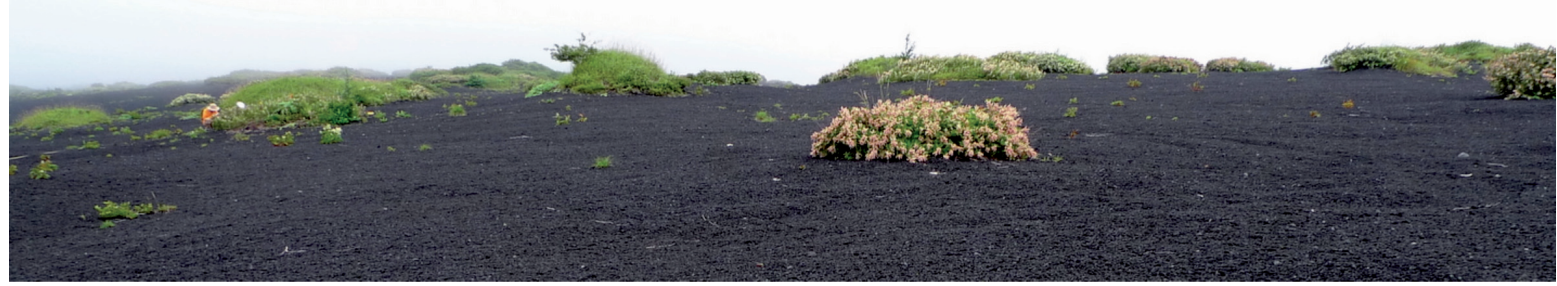

Figure 1. Patches of Polygonum cuspidatum on barren scoria gravel in the slopes of Mt Fuji, Japan at $1500 \mathrm{~m}$ elevation. 
Table 1. Plant community structure at sites of different elevations (m a.s.l.), volcanic desert of Mount Fuji, Japan. Empty cells denotes absence of the species, and + refers to $<1 \%$ cover.

\begin{tabular}{|c|c|c|}
\hline \multirow[t]{2}{*}{ Species } & \multicolumn{2}{|c|}{ Cover $(\%)$} \\
\hline & $1500 \mathrm{~m}$ & $1930 \mathrm{~m}$ \\
\hline Miscanthus oligostachyus & 30 & \\
\hline Polygonum cuspidatum & 25 & 85 \\
\hline Salix reinii & 15 & \\
\hline Clematis stans & 10 & \\
\hline Cirsium purpuratum & 5 & 5 \\
\hline Polygonum weyrichii var. alpinum & 2 & 10 \\
\hline Anaphalis margaritacea & 1 & \\
\hline Arabis serrata & 1 & + \\
\hline Artemisia pedunculosa & 1 & \\
\hline Artemisia princeps & 1 & \\
\hline Aster ageratoides var. ovatus & 1 & \\
\hline Astragalis adsurgens & 1 & \\
\hline Campanula punctata ssp. hondoensis & 1 & \\
\hline Carex doenitzii & 1 & \\
\hline Cirsium effusum & 1 & \\
\hline Hedysarum vicioides & 1 & \\
\hline Picris hieracioides ssp. japonica & 1 & \\
\hline Senecio nemorensis & 1 & \\
\hline Stellaria nipponica & 1 & \\
\hline Angelica hakonensis & + & \\
\hline Betula ermanii & + & \\
\hline Fragaria nipponica & + & \\
\hline Larix kaempferi & + & \\
\hline Ligustrum obtusifolium & + & \\
\hline Rosa fujisanensis & + & \\
\hline Salix bakko & + & \\
\hline Spiraea japonica & + & \\
\hline Weigela decora & + & \\
\hline
\end{tabular}

from ca 4 to 0.5 per patch respectively, so that there is a tight correlation between plant species richness and the number of AM spore morphotypes (Wu et al. 2007).

Different mechanisms may generate these patterns, although it is unclear whether plant species richness declines with increasing elevation because there are less AM spores available, or if there are less AM spores because their host plants are absent at high elevation. On Mount St Helens, it was found that AM spores migrated primarily in association with migrating gophers (Allen et al. 1984, 1992, Allen 1987, Allen and MacMahon 1988). In strand vegetation of Hawaiian coast, Koske and Gemma (1990) found a close association between propagules of AM and vegetative fragments of indigenous plants, suggesting a mechanism for co-dispersal of plants and fungi. At high elevation on Mount Fuji, AM are only found in the roots of P. cuspidatum and C. purpuratum. In P. cuspidatum infection rate is low ( $25 \%$ at $1500 \mathrm{~m}, 2 \%$ at $1939 \mathrm{~m}$, Wu et al. 2007). Laboratory experiments could not detect any benefits for P. cuspidatum from being infected by AM, and in these experiments infection rate remained low (Fujiyoshi et al. 2006). There is evidence that AM infection may reduce fitness of $P$. cuspidatum as infected individuals tended to be smaller than uninfected ones (Wu unpubl.). It can be rea- 
sonably speculated that $P$. cuspidatum barely tolerates AM infection, and that this tolerance may be a key for starting succession by allowing other AM-dependent species to associate with $P$. cuspidatum and form growing vegetation patches.

The role of other pioneer species such as $C$. purpuratum, a mycorrhizal species, may be different. Experiments show that $C$. purpuratum can facilitate other species (e.g. Clematis stans) through AM (Wu et al. unpubl.). On sterile soils both species were competing with each other, whereas on natural soils, i.e. with AM inocula, C. purpuratum facilitated growth of C. stans. AM infection rate in C. purpuratum on natural soil reached $74 \%$ after eight weeks of the experiment, but in $C$. stans AM infection rate depended on the distance from $C$. purpuratum, and seedlings of $C$. stans grew 30 to $60 \%$ when planted, respectively, at 15 and $5 \mathrm{~cm}$ from $C$. purpuratum (Miyata et al. unpubl.). Thus, seedlings of $C$. stans close to $C$. purpuratum grew 2-3 times larger, so that facilitation also depended on the distance between plant individuals and was greatest near C. purpuratum (Wu et al. unpubl.). Overall, these data show that AM are involved in the outcome of plant-plant interactions during the first stages of primary succession, and make possible the co-occurrence of pioneer and latesuccessional species in patches, accelerating succession by facilitating late-successional species. It is known that mycorrhiza can alter plant-plant interactions and play a key role in facilitating seedling establishment (van der Heijden and Horton 2009). Many mycorrhizal fungi are not host-specific (Trappe 1987) and one fungal individual can colonize and interconnect a considerable number of plants (Beiler et al. 2010, Yang et al. 2010). The existence of these so-called mycorrhizal networks implies that fungi have the potential to redistribute resources among plants irrespective of their size, status or identity, so that AM and EM can be involved both in facilitative or competitive effects of plants on each other (Moora and Zobel 2010). Probably, AM act as mediators of interactions between plants of different successional stages. Studying primary succession in several systems and biogeographical comparisons may help to find whether tolerance to AM in pioneer species is generally an important mechanism of primary succession.

\section{Primary successions in sand dunes and semi- deserts}

Sand dunes represent a classic system where succession has been studied since the times of Cowles (1911). However, sand dunes were mostly approached to study cyclical succession and less as primary succession (Read 1989, Mueller 1999, Alarcón and Cuenca 2005, Camprubi et al. 2010, Gormally and Donovan 2010). The question of AM-mediated plant-plant interactions in sand dunes also attracted some interest from researchers so that some preliminary information concerning the presence and role of
AM already exists (Koske and Polson 1984, Sigüenza et al. 1996, Kowalchuk et al. 2002, Rilling et al. 2003, Rodríguez-Echeverría and Freitas 2006, Rodríguez Echeverría et al. 2008, Blaszkowski et al. 2009, Martínez-García 2010).

Sand dunes in Cabo de Gata Nature Park $\left(36^{\circ} 50^{\prime} \mathrm{N}\right.$, $\left.2^{\circ} 23^{\prime} \mathrm{W}\right)$ in Almería, Spain are characterized by a patchy distribution of resources under or around dominant $\mathrm{Ziz}_{\mathrm{z}}$ iphus lotus, a thorny shrub that forms large hemispherical canopies 1-3 $\mathrm{m}$ in height and congregates many other species of shrubs and herbs. Each $Z$. lotus canopy covers approximately $10-20 \mathrm{~m}^{2}$. Microclimatic conditions inside the canopy are mild, and there is more organic matter, available phosphorus, and total nitrogen than in open areas (Tirado and Pugnaire 2003). In general, 'fertility islands' associated with $Z$. lotus have high levels of mycorrhizal inocula. In these sand dunes herbaceous perennial plants as Ballota hirsuta and Lobuaria maritima grow both in patches of $Z$. lotus and in open areas. Data show that there is a degree of species-specificity in shrub-AM associations, which may indicate a control of AM on plant population and community dynamics in arid ecosystems; in this system, pair-wise comparisons showed that AM associated with Ballota were genetically different from those associated with Lobularia (Martínez-García and Pugnaire 2009, Martínez-García 2010, Pugnaire and MartínezGarcía unpubl.). However, re-analysis of existing data on plant interactions and community dynamics in sand dune systems (Pugnaire et al. 2006, Armas and Pugnaire 2009, Armas et al. 2010) and its relations with AM fungal communities may be helpful for establishing an appropriate natural model of primary successions on sand dunes.

Another system which may serve as a model of primary succession are arid deserts with locally intensive erosion processes, such as Tabernas in Spain, located in the northern foothills of Sierra Alhamilla range $\left(37^{\circ} 01^{\prime} \mathrm{N}, 2^{\circ} 25^{\prime} \mathrm{W}\right)$, Almería province. Locally intense erosion (Cantón et al. 2001, 2002) refers to sites where erosion exposes new land surface after strong rainfall events. Eroded areas can essentially be considered subjected to primary succession. Preliminary information concerning the presence and role of $A M$ in vegetation processes already exists for this area (Martínez-García 2010, Martínez-García et al. 2011). In particular, differences in AM fungi composition have been documented in soils under different shrub species and in gaps among them, whereas no differences were detected among AM colonizing roots. Soil nutrient content drove most of the spatial variations in AM genetic diversity, which was more homogeneous in fertile islands with high nitrogen-to-phosphorus ratio. AM diversity increased in soils limited by phosphorus and with high organic matter content but also in roots of shrubs growing in soil not limited by phosphorus. Although no clear link was found between AM diversity and plant performance, results pointed out the existence of plant-soil feedbacks under different shrub species. Recent studies have highlighted the importance of plant-soil feedbacks on successional dynamics (Hart et 
al. 2003, Reynolds et al. 2003, Bonanomi et al. 2005). Reynolds et al. (2003) suggested that positive feedbacks between plants and soil microbes play a central role in early successional communities, while negative feedbacks contribute both to species replacement and coexistence and diversification in late-successional communities. Overall, primary succession in edaphic deserts leads to the question of how plants under water stress depend on AM symbiosis (Allen 2007).

Addressing primary succession under different ecological systems is critical to characterize and understand the role of AM in this basic process. While volcanoes and glaciers are restricted to particular mountainous areas, naturally eroded areas and sand dunes are more common and easily accessible, making them attractive models to address primary succession.

Acknowledgements - This study was supported by a JSPS-CSIC joint project (ref. 2008JP008). Additional support was provided by the Spanish MICINN (ref. CGL2007-637187).

\section{References}

Adachi, N. et al. 1996. Central die-back of monoclonal stands of Reynoutria japonica in an early stage of primary succession on Mount Fuji. - Ann. Bot. 77: 477-486.

Alarcón, C. and Cuenca, G. 2005. Arbuscular mycorrhizas in coastal sand dunes of the Paraguaná Peninsula, Venezuela. Mycorrhiza 16: 1-9.

Allen, M. F. 1987. Re-establishment of mycorrhizas on Mount St Helens: migration vectors. - Trans. Brit. Mycol. Soc. 88: 413-417.

Allen, M. F. 2007. Mycorrhizal fungi: highways for water and nutrients in arid soils. - Vadose Zone J. 6: 291-297.

Allen, M. F. and MacMahon, J. A. 1988. Direct VA mycorrhizal inoculation of colonizing plants by pocket gophers (Thomomys talpoides) on Mount St Helens. - Mycologia 80: 754-756.

Allen, M. F. et al. 1984. Reestablishment of Endogonaceae on Mount St Helens: survival of residuals. - Mycologia 75: 1031-1038.

Allen, M. F. et al. 1992. Re-formation of mycorrhizal symbioses on Mount St Helens, 1980-1990: interactions of rodents and mycorrhizal fungi. - Mycol. Res. 96: 447-453.

Allen, M. F. et al. 2003. Ecology of mycorrhizae: a conceptual framework for complex interactions among plants and fungi. - Ann. Rev. Phytopath. 41: 271-303.

Aplet, G. H. et al. 1998. Ecosystem development on Hawaiian lava flows: biomass and species composition. - J. Veg. Sci. 9: 17-26.

Armas, C. and Pugnaire, F. I. 2009. Ontogenetic shifts in interactions of two dominant shrub species in a semi-arid coastal sand dune system. - J. Veg. Sci. 20: 535-546.

Armas, C. et al. 2010. Hydraulic lift and tolerance to salinity of semiarid species: consequences for species interactions. Oecologia 162: 11-21.

Beiler, K. J. et al. 2010. Architecture of the wood-wide web: Rhizopogon spp. genets link multiple Douglas-fir cohorts. New Phytol. 185: 543-553.
Blaszkowski, J. et al. 2009. Glomus achrum and G. bistratum, two new species of arbuscular mycorrhizal fungi (Glomeromycota) found in maritime sand dunes. - Can. J. Bot. 87: 260-271.

Bonanomi, G. et al. 2005. Negative plant-soil feedback and species coexistence. - Oikos 111: 311-321.

Brundrett, M. C. 2002. Coevolution of roots and mycorrhizas of land plants. - New Phytol. 154: 275-304.

Camprubi, A. et al. 2010. Arbuscular mycorrhizal fungi associated with psammophilic vegetation in Mediterranean coastal sand dunes. - Span. J. Agric. Res. 8: S96-S102.

Cantón, Y. et al. 2001. Hydrological and erosion response of a badland system in semiarid SE Spain. - J. Hydrol. 252: 56-84.

Cantón, Y. et al. 2002. Influence of soil-surface types on the overall runoff of the Tabernas badlands (southeast Spain): field data and model approaches. - Hydrol. Proc. 16: 26212643.

Cázares, E. et al. 2005. Mycorrhiza-plant colonization patterns on a subalpine glacier forefront as a model system of primary succession. - Mycorrhiza 15: 405-416.

Cowles, H. 1911. The causes of vegetational cycles. - Ann. Assoc. Am. Geograph. 1: 3-20.

Cripps, C. L. and Eddington, L. H. 2005. Distribution of mycorrhizal types among alpine vascular plant families on the Beartooth Plateau, Rocky Mountains, USA, in reference to large-scale patterns in arctic-alpine habitats. - Arct. Antarct. Alp. Res. 37: 177-188.

del Moral, R. 2010. The importance of long-term studies of ecosystem reassembly after the eruption of the Kasatochi Island Volcano. - Arct. Antarct. Alp. Res. 42: 335-341.

del Moral, R. and Eckert, A. J. 2005. Colonization of volcanic deserts from productive patches. - Am. J. Bot. 92: 27-36.

del Moral, R. and Jones, C. 2002. Vegetation development on pumice at Mount St Helens, USA. - Plant Ecol. 162: 9-22.

del Moral, R. and Rozzell, L. R. 2005. Long-term effects of Lupinus lepidus on vegetation dynamics at Mount St Helens. - Plant Ecol. 81: 203-215.

del Moral, R. and Wood, D. M. 1993. Early primary succession on the volcano Mount St Helens. - J. Veg. Sci. 4: 223-234.

del Moral, R. et al. 1995. Early primary succession on Mount St Helens, Washington, USA. - J. Veg. Sci. 6: 107-120.

Dimopoulos, P. et al. 2010. Vegetation patterns and primary succession on sea-born volcanic islands (Santorini archipelago, Aegean Sea, Greece). - Phytocoenologia 40: 1-14.

Fujiyoshi, M. et al. 2005. Successional changes in mycorrhizal type in the pioneer plant communities of a subalpine volcanic desert on Mt Fuji, Japan. - Polar Biosci. 18: 60-72.

Fujiyoshi, M. et al. 2006. Effects of arbuscular mycorrhizal fungi and soil developmental stages on herbaceous plants growing in the early stage of primary succession on Mount Fuji. Ecol. Res. 21: 278-284.

Fuller, R. N. and del Moral, R. 2003. The role of refugia and dispersal in primary succession on Mount St Helens, Washington. - J. Veg. Sci. 14: 637-644.

Garbarino, M. et al. 2010. Patterns of larch establishment following deglaciation of Ventina glacier, central Italian Alps. - For. Ecol. Manage. 259: 583-590.

Gormally, C. L. and Donovan, L. A. 2010. Responses of Uniola paniculata L. (Poaceae), an essential dune-building grass, to 
complex changing environmental gradients on the coastal dunes. - Estuar. Coast. 33: 1237-1246.

Hart, M. M. et al. 2003. Plant coexistence mediated by arbuscular mycorrhizal fungi. - Trends Ecol. Evol. 18: 418-423.

Helm, D. J. et al. 1996. Mycorrhizal chronosequence near Exit Glacier, Alaska. - Can. J. Bot. 74: 1496-1506.

Hirose, T. and Tateno, M. 1984: Soil nitrogen patterns induced by colonization of Polygonum cuspidatum on Mt Fuji. - Oecologia 61: 218-223.

Koske, R. and Polson, W. 1984. Are VA mycorrhizae required for sand dune stabilization? - Bioscience 34: 420-424.

Koske, R. E. and Gemma, J. N. 1990. VA mycorrhizae in strand vegetation of Hawaii: evidence for long-distance codispersal of plants and fungi. - Am. J. Bot. 77: 466-474.

Kowalchuk, G. A. et al. 2002. Community analysis of arbuscular mycorrhizal fungi associated with Ammophila arenaria in Dutch coastal sand dunes. - Mol. Ecol. 11: 571-581.

Marteinsdottir, B. et al. 2010. Development of vegetation patterns in early primary succession. - J. Veg. Sci. 21: 531540.

Martínez, L. B. and Pugnaire, F. I. 2009. Interacciones entre las comunidades de hongos formadores de micorrizas arbusculares y de plantas. Algunos ejemplos en los ecosistemas semiáridos. - Ecosistemas 18: 44-54.

Martínez-García, L. B. 2010. Micorrizas arbusculares en ecosistemas semiáridos. Respuesta a factores de estrés ambiental. Interacciones entre la comunidad vegetal y los hongos formadores de micorrizas arbusculares. Estudio concreto de los ecosistemas semiáridos. - PhD thesis, Univ. de Almeria, Almería, Spain.

Martínez-García, L. B. et al. 2011. Shrubs influence arbuscular mycorrhizal fungi communities in a semiarid environment. - Soil Biol. Biochem. in press.

Maruta, E. 1976. Seedling establishment of Polygonum cuspidatum on Mt Fuji. - Jap. J. Ecol. 26: 101-105.

Masuzawa, T. 1995. Successional process on Mt Fuji: from alpine herbaceous perennials to dwarf scrub. - In: Box, E. O. et al. (eds), Vegetation science in forestry. Kluwer, pp. 423-431.

Masuzawa, T. 1997. Ecology of the alpine plants. - Univ. of Tokyo Press.

Masuzawa, T. and Suzuki, J. 1991. Structure and succession of alpine perennial community (Polygonum cuspidatum) on $\mathrm{Mt}$ Fuji. - Proc. NIRP Symp. Polar Biol. 4: 155-160.

Moora, M. and Zobel, M. 2010. Arbuscular mycorrhizae and plant-plant interactions. Impact of invisible world on visible patterns. - In: Pugnaire, F. I. (ed.), Positive plant interactions and community dynamics. CRC Press.

Morte, A. et al. 2000. Effect of drought stress on growth and water relations of the mycorrhizal association Helianthemum almeriense-Terfezia claveryi. - Mycorrhiza 10: 115-119.

Mueller, J. 1999. Small scale vegetation dynamics in permanent plots on coastal dunes. - Faunist.-Oekol. Mitteil. Suppl. 26: $33-48$.

Nara, K. 2006. Pioneer dwarf willow may facilitate tree succession by providing late colonizers with compatible ectomycorrhizal fungi in a primary successional volcanic desert. New Phytol. 171: 187-198.

Nishitani, S. and Masuzawa, T. 1996. Germination characteristics of two species of Polygonum in relation to their altitudinal distribution on Mt Fuji, Japan. - Arct. Antarct. Alp. Res. 28: $104-110$.
Obase, K. et al. 2007. Mycorrhizal associations in woody plant species at the Mt Usu volcano, Japan. - Mycorrhiza 17: 209-215.

Obase, K. et al. 2008. Mycorrhizal colonization status of plant species established in an exposed area following the 2000 eruption of Mt Usu, Hokkaido, Japan. - Landsc. Ecol. Eng. 4: 57-61.

Pezzani, F. et al. 2006. Associations between arbuscular mycorrhizal fungi and grasses in the successional context of a twophase mosaic in the Chihuahuan Desert. - Mycorrhiza 16: 285-295.

Pugnaire, F. I. et al. 2006. Colonization processes in semi-arid Mediterranean old-fields. - J. Arid Environ. 65: 591-603.

Read, D. J. 1989. Mycorrhizas and nutrient cycling in sand dune ecosystems. - Proc. R. Soc. Edinb. B. 96: 89-110.

Reynolds, H. L. et al. 2003. Grassroots ecology: Plant-microbesoil interactions as drivers of plant community structure and dynamics. - Ecology 84: 2281-2291.

Rillig, M. C. et al. 2003. Microsite differences in fungal hyphal length, glomalin, and soil aggregate stability in semiarid Mediterranean steppes. - Soil Biol. Biochem. 35: 1257-1260.

Robbins, J. A. and Matthews, J. A. 2010. Regional variation in successional trajectories and rates of vegetation change on glacier forelands in south-central Norway. - Arct. Antarc. Alp. Res. 42: 351-361.

Rodriguez-Echeverria, S. and Freitas, H. 2006. Diversity of AMF associated with Ammophila arenaria ssp. arundinacea in Portuguese sand dunes. - Mycorrhiza 16: 543-552.

Rodriguez-Echeverria, S. et al. 2008. Arbuscular mycorrhizal fungi of Ammophila arenaria (L.) Link: spore abundance and root colonisation in six locations of the European coast. - Eur. J. Soil Biol. 44: 30-36.

Sigüenza, C. et al. 1996. Seasonality of mycorrhizae in coastal sand dunes of Baja California. - Mycorrhiza 6: 151-157.

Sklenáŕ, P. et al. 2010. Primary succession of high-altitude Andean vegetation on lahars of Volcán Cotopaxi, Ecuador. Phytocoenologia 40: 15-28.

Tian, C. et al. 2006. Arbuscular mycorrhizal associations in the Gurbantunggut Desert. - Chinese Sci. Bull. 51: 140-146.

Tirado, R. and Pugnaire, F. I. 2003. Shrub spatial aggregation and consequences for reproductive success. - Oecologia 136: 296-301.

Titus, J. H. and Tsuyuzaki, S. 2003. Distribution of plants in relation to microsites on recent volcanic substrates on Mount Koma, Hokkaido, Japan. - Ecol. Res. 18: 91-98.

Titus, J. H. and del Moral, R. 1998a. The role of mycorrhizae in primary succession on Mount St Helens. - Am. J. Bot. 85: 370-375.

Titus, J. H. and del Moral, R. 1998b. Vesicular-arbuscular mycorrhizae influence Mount St Helens pioneer species in greenhouse experiments. - Oikos 81: 495-510.

Trappe, J. M. 1987. Phylogenetic and ecologic aspects of mycotrophy in the angiosperms from an evolutionary standpoint. Ecophysiology of VA mycorrhizal Plants Florida, USA CRC Press.

Trowbridge, J. and Jumpponen, A. 2004. Fungal colonization of shrub willow roots at the forefront of a receding glacier. Mycorrhiza 14: 283-293.

Tsuyuzaki, S. and Hase, A. 2005. Plant community dynamics on the volcano mount Koma, northern Japan, after the 1996 eruption. - Folia Geobot. 40: 319-330. 
Tsuyuzaki, S. et al. 2005. Distribution of different mycorrhizal classes on Mount Koma, northern Japan. - Mycorrhiza 15: 93-100.

Tu, M. et al. 1998. Composition and dynamics of wetland seed banks on Mount St Helens, Washington, USA. - Folia Geobot. 32: 3-16.

van der Heijden, M. G. A. and Horton, T. R. 2009. Socialism in soil? The importance of mycorrhizal fungal networks for facilitation in natural ecosystems. - J. Ecol. 97: 1139-1150.

Walker, L. R. et al. 2003. Colonization dynamics and facilitative impacts of a nitrogen-fixing shrub in primary succession. $-\mathrm{J}$. Veg. Sci. 14: 277-290.

Walker, L. R. et al. 2009. Applying lessons from ecological succession to the restoration of landslides. - Plant Soil 324: 157-168.

Wood, D. M and del Moral, R. 1987. Mechanisms of early primary succession in subalpine habitats on mount St Helens. - Ecology 68: 780-790.
Wu, B. et al. 2001. Can ${ }^{14} \mathrm{C}$-labeled photosynthetic products move between Pinus densiflor seedlings linked by ectomycorrhizal mycelia? - New Phytol. 149: 137-146.

Wu, B. et al. 2004. Arbuscular mycorrhizal colonization of the dominant plant species in primary successional volcanic deserts on the southeast slope of Mount Fuji. - Mycorrhiza 14: 391-395.

Wu, B. et al. 2007. Community structure of arbuscular mycorrhizal fungi in a primary successional volcanic desert on the southeast slope of Mount Fuji. - Mycorrhiza 17: 495-506.

Yang, C. et al. 2010. Diversity and functionality of arbuscular mycorrhizal fungi in three plant communities in semiarid Grasslands National Park, Canada. - Microbial Ecol. 59: 724-733.

Zhou, Z. et al. 2003. Patch establishment and development of a clonal plant, Polygonum cuspidatum, on Mount Fuji. - Mol. Ecol. 12:1361-1373. 